\title{
Article
}

\section{Content marketing from the perspective of PR specialists: an Estonian case study}

$\$$ sciendo

KRISTEL ABEL, Tallinn University, Estonia, kristel.abel@tlu.ee TIINA HIOB, Tallinn University, Estonia, tiina.hiob@tlu.ee ESTA KAAL, Tallinn University, Estonia, estak@tlu.ee MART SOONIK, Tallinn University, Estonia, soonikm@tlu.ee

RAIN VEETÕUSME, Tallinn University, Estonia, rainvee@tlu.ee 


\section{ABSTRACT}

This paper is an exploratory study to understand the content marketing practices in Estonia, a current trend that ties together journalism, communications, and advertising. Estonia is a small market where the 'guilds' of journalists and PR professionals are rather intertwined. Trends occurring here may provide suggestions for larger markets and future developments. A qualitative study was conducted in Spring 2018. The objective of the study was to describe the problems and potential complications arising from the reorganization of traditional areas of activity of agents operating in the field of the communications industry - specifically in the context of content marketing, and from the viewpoint of representatives of PR agencies. The article begins with putting the phenomenon of content marketing into a wider societal context and specifically that of the Estonian media ecosystem. The possible influences of content marketing on such important realms, and such defining factors as trust (Luhmann 2000), social capital (Bourdieu 1995) the integrity, independence, and the interactions between the different fields (ibid) are discussed. The results of the survey indicate that the field of public relations is changing as a result of the forces from the other neighbouring fields, that of journalism and advertising. The paper points out that the issue of trust and trustworthiness and the origins of 'the media' need to be addressed in order to provide integrity and transparency.

INTRODUCTION

In 2014, Macnamara indicated that "it is likely that the interrelationships between journalism and PR has been examined in 200 or more research studies." Despite that, there are several reasons that future research is required. For instance, new media formats and practices are changing the nature of journalism and PR. "New

\footnotetext{
types of "owned" media enabled by the boom of online publishing, with bypass "gatekeepers" and the development of new sponsored content formats, referred to as embedded marketing, native advertising and other terms are potentially increasing the influence of PR and warrant close attention". (Macnamara 2014:740)
} 
The study that covered almost the whole of Europe drew out trends, that mass media is losing ground in Western and Northern Europe. At the same time it indicated that there can be very significant differences between countries and regions (Zerfass et al. 2016).

The paper relies on current research in content marketing. At the end of the first decade of this century a new trend became common in the press, whereby marketing, which had formerly used advertising spaces, started to infiltrate into journalistic content (Wybenga 2013).

This process has inevitably brought along certain aspects, which has redesigned several classic rules of journalism. Thereby, changes have occurred not only in the behaviour of the press as a whole, but also in the habits of consumers to ingest what the press feeds them. Expectations of the public towards the press, and also the expectations of the advertisers of services offered by various media formats have also changed considerably. Although these changes concern almost all media platforms, in this study, we concentrate mainly on the changes taking place in the realm of online media.

To date, there haven't been many academic studies conducted in Estonia in this field or covering these topics regardless of the fact that content marketing has been utilised for a number of years by communications and advertising agencies in this country. Some media houses have separate in-house divisions that specifically provide content marketing services, i.e. content writing, and also an entire suite of channels to promote the stories their clients wish to communicate. Estonian research so far has been introductory, several bachelor's level theses have tackled the issue (eg Vohu 2016; Luide 2018; Kärtner 2019) but further research is necessary before any in-depth conclusions can be drawn. This paper is the first attempt to approach the topic academically. It aims to point out the concepts and practices of content marketing, through an Estonian PR perspective.
Public relations as a field operates in the vicinity of two other fields: journalism and advertising. The lines are blurred between the fields of journalism, public relations, and advertising - all of which provide a skilled narrative, creation or interpretation of key concepts, and in most cases use the written word to communicate their ideas to their intended audience. All three compete in the communications market, and operate using the same resources. These fields seem to collide in content marketing, especially in Estonian context.

This research sets about with the objective to clarify the problems arising from the reorganisation of traditional areas of activity by the players operating in the field of the communications industry. This has been done in the context of content marketing, based on the point of view of representatives from Estonian PR agencies.

\section{THEORETICAL FRAMEWORK}

As this paper focuses on changes at a societal level, the definition of public relations as set in the Bled Manifesto is used: "the maintenance of relationships with publics by communication in order to establish mutual understanding" (van Ruler, Verčič 2002:13).

As such, public relations is a field
that can be described similarly
to how French sociologist Pierre
Bourdieu defines a field: "A field
is a field of forces within which
the agents occupy positions that
statistically determine the posi-
tions they take with respect to the
field, these position-takings be-
ing aimed either at conserving of
transforming the structure of rela-
tions of forces that is constitutive
of the field." (Bourdieu 1995:30)

Bourdieu describes the field of journalism as a microcosm following its own rules and journalists as agents of the journalistic fiel, ibid. Similarly, journalists shape the discussions through mass media that is widely 
viewed as the central institution of the contemporary public sphere. (Benson 2001) The public sphere today is, to a large extent, influenced and shaped by public relations. Public relations specialists, but also brand evangelists or haters provide their views and create their own narratives. This has blurred the lines between the fields of journalism, public relations and advertising, adding value to skilled narrative creation, and writing. More studies have been done recently on the subject, eg Cornia, Sehl and Nielsen (2018) who focussed on the growing understanding of news organizations' editing and advertising department. Changing relationships of PR and journalism have been addressed in papers like dr Yuan Zeng (2018) who focussed on the changes to journalism and its integrity:

With the increasing financial pressures facing traditional news organizations, journalists, whether freelancers or staff reporters, are moving into this field and applying their journalistic skills in the service of advocacy or marketing content, triggering ethical concerns. Journalists moving between content marketing and traditional journalism are seen as upsetting the already delicate balance between public-service journalism and content creation for commercial purposes.

Public relations aim to build and maintain mutual understanding in their target audience. There are many tools in the PR specialists' toolbox to do that, and the skill of writing is the most essential one, and has been identified as the core skill of the field (Cutlip et al. 2000). Furthermore, it is among a professional communicator's most marketable skills, and is perhaps the most challenging to acquire (Hardin, Pompper 2004; CIPR 2012). Today we witness that the central skill, to create and write a client's story, is being transferred through the appearance of content marketing and brand journalism through the institution of traditional journalism, client's own channels as well as advertising agencies.

In this paper, the central term used to describe the aforementioned phenomenon is "content marketing", and this method is quite widespread in Estonia. However, overlapping may occur also with other related terms, such as native advertising and hybrid content. Content marketing was until recently known in Estonia as "advertising articles". It is still unclear whether only the title was changed in order to be more appealing to the customers and trustworthy to the readers.

Native advertising is defined as the form of any paid advertising presented in the media, in the form of edited content (Wojdynski, Evans 2016). In Estonia, a major media channel has attempted to define the term: the marketing channel Bestmarketing.ee of the online version of the business paper Äripäev. Their equivalent for native advertising is fused advertising (Best Marketing 2015). Hybrid content is described as journalistic content, the objective of which is not only journalistic (Taiminen et al. 2015), while content marketing is defined as strategic marketing technology used for creating and disseminating valuable, relevant and consistent content, in order to attract and acquire a clearly specified audience, with the objective to control profitable behaviour of customers through changing or increasing that behaviour of consumers (Pulizzi 2015).

\section{GLOBAL AND \\ LOCAL FRAMEWORK}

Although the global economic situation also has a major effect on advertising revenue, the common trend has been clear in the last 15 years - sales numbers of advertising in paper publications have decreased, while advertising volume in online or digital channels have increased. (PriceWaterhouseCoopers 2009, 2011, 2016)

\section{Advertising sector in Estonia}

Blurring of borders between Public Relations, advertising and journalism in Estonia has already been addressed earlier and this 
trend has not diminished. On the contrary: there also seems to be the development of an augment that there are some elements of the media market for whom survival means overlooking the difference between paid (compromised) and independent information. (Harro-Loit, Saks 2006)

In a situation where the press is involved in underfunding, the need for advertising money is obvious. At the same time consumers have adapted to ignore the advertisements. The consumers of online media develop advertising blindness quite quickly (Benway, Lane 1998). Media channels have tried to save web advertising, thereby making it more aggressive. As a result, consumers increasingly want to get rid of it, adopting software updates or add-ons in web browsers, which are called 'ad blockers' (Vallade 2009). According to the data of the service provider PageFair (2017) monitoring ad blockers in the browsers of visitors of web pages, $11 \%$ of internet equipment across the globe used some type of ad blocker by the end of 2016, while the relevant number in Estonia was 26\%. While the global annual relevant increase was 30\%.

This, in turn, leads to the need to implement ways of advertising that could bypass ad blockers and ad avoidance in general. As a result, today we can see a variety of advertising techniques and ways which confuses consumers and readers. There are similar trends in Estonia that Wybenga (2013) mentions: for consumers, it makes it harder to distinguish commercial and journalistic content.

Estonian Consumer Protection and Technical Regulatory Authority who is responsible for supervision of Unfair Commercial Practices including advertising is in difficult situation unable to distinguish promotional material and unpaid content. Nor is the situation with the press any easier. The worrying aspect is that the control mechanisms of legislation, the Journalism Code of Ethics and the idea of good journalistic practice are either being ignored or misused. (Harro-Loit, Saks 2006)
Journalism is based on reliability and transparency. However, the online era has introduced a new business model for journalism, where advertisements move into journalistic content, having a negative impact on reliability (Wybenga 2013) and transparency (Taiminen et al. 2015).

The reliability of the press is also undermined by media channels, which do not seek the truth (Rubin et al. 2015). Also, it has become consistently more difficult to discern true journalists from mere bloggers (Fulton 2015). At the same time, the globalisation of the media has taken place, making regulations proceeding from the territory of countries more complicated (Flew, Waisbord 2015).

A survey conducted among European PR professionals shows, that in different regions, there are quite different approaches to media relations, as well as content marketing relationships and perspectives. Northern Europe gives a more prominent role to content marketing than other European regions (Zerfass et al. 2016).

Similarly to other Nordic countries, the Estonian advertising market had long concentrated on print media. The situation changed in 2011/2012, when television became the medium with the highest turnover, and by 2016 the internet or online advertising exceeded the turnover of print advertising. In 2017, 25\% of advertising budgets circulating in the Estonian advertising market were targeted to television, $20 \%$ to web media (not including the turnover of Google and Facebook), and $17 \%$ to newspapers. (Kantar Emor 2018a)

In 2017 the Estonian advertising market grew by $3 \%$ compared to 2016 , including an increase in web advertising by $8.3 \%$ (except Google, Facebook). During the same period the funds for online advertising spent on Google and Facebook advertisement from Estonia increased by $40 \%$. (Kantar Emor 2018b)

\section{Press sector in Estonia}

As the Estonian press market is small but people's attention and trust in the media is 
above average, the changes in the Estonian market are rapid and give an indication of possible future developments in other markets. (TNS opinion \& social 2018)

The population of Estonia as of January 01, 2018 was 1,319,133 (Statistics Estonia 2018b). This market includes approximately 300 media channels, the content of which is produced mainly in Estonia (Journalists.ee 2018). These figures do not include numerous blogs, social media channels, or publications with an irregular publishing frequency. At the same time, most major media outlets across the country belong to only a few major media houses.

In Estonia, the credibility rating of the press is traditionally high. According to a survey produced by Eurobarometer conducted in the autumn of $2017,42 \%$ of the Estonian population has a medium-level, and $29 \%$ have a high trust in the media. The relevant average results of the European Union are $41 \%$ and $21 \%$ in comparison. (TNS opinion \& social 2017)

$87.6 \%$ of Estonian residents between the ages of 16-74 years use the internet (Statistics Estonia 2018a). The reading of paper versions of newspapers and periodicals has decreased dramatically. While in the year $2000,5 \%$ of the population did not read paper publications, by 2015 this number had grown to $26 \%$. However, the interest in news has not decreased, but channels have changed (Vihalemm et al. 2017:254-259).

\section{According to World Press Freedom} Index, Estonia holds the 12 position in the global list of press freedom (Reporters Without Borders 2018). On a legal level, the media is rather loosely regulated in Estonia. The main aspects concerning media proceed from three acts: The Media Services Act (Riigi Teataja 2010), The Estonian Public Broadcasting Act (Riigi Teataja 2007) and The Advertising Act (Riigi Teataja 2008).

The central organisation at the head of self-regulation of the press in Estonia is the Estonian Newspaper Association (EALL) ${ }^{1}$.

Due to the expansion of the membership, in april 2019 Estonian Newspaper Association (EALL), changed the name to Estonian Association of Media Enterprises.
The central document of self-regulation is The Code of Ethics of the Estonian Press, prepared by EALL (EALL 1998). In addition to the Code of Ethics, the EALL has Good practice agreements (EALL 2019c), that regulate phone sales (EALL 2015a, Eesti Otseturunduse Liit 2015), fixing mistakes in web (EALL 2015), online commentaries (EALL 2008), distinction between advertising and content (EALL 2016), citation of articles (EALL 2005b), copyright (EALL 2004) and EALL membership criteria (EALL 2005a). With complaints against the press deals The Estonian Press Council of EALL (EALL 2019b).

But there is another control organization. The Estonian Press Council, which members are the Estonian Association of Journalists, Estonian Media Educators Association, Estonian Consumers Union, Estonian Lawyers Union and NGO Meediaseire (Avaliku Sõna Nõukogu 2019a).

Both organizations are called The Estonian Press Council in English. However, the names in Estonian are different. The Estonian Press Council of EALL name is "Pressinõukogu", in a direct translation Press Council (PN). The name of the parallel organization is "Avaliku Sõna Nõukogu" (ASN), in direct translation the Council of the Public Word.

The Estonian Press Council (ASN), also relies on the same Code of Ethics, but this organization has lower authority in society than The Estonian Press Council (PN). In 2018 The Estonian Press Council (PC) proceeded with 84 claims (EALL 2019a) and The Estonian Press Council (ASN) processed 19 claims of violation (Avaliku Sõna Nõukogu 2019b).

\section{PR sector in Estonia}

Based on OSKA research 2019 (labour market monitoring and future skills forecasting research; OSKA is funded from the European Social Fund) there are 1200 people working in the field of public relations and communication in Estonia. Based on interviews with experts it could be argued that marketing and public relations skills will be merged in the future even more and it is 
rising trend in Estonian market. There is a significant growth - from 768 public relations professionals in 2011 to the average of 890 people in 2014-2016. We can see also grown number of executives in communication field from 590 to 850 over the same years. (Krusell, Pihl 2019)

Estonian Public Relations Association was founded in 1996 as an umbrella organisation for Estonian public relations professionals. It's mission is to support professionalism and promote public relations in Estonia. The association follows it's Code of Ethics that is based on the International Public Relations Association Code of Conduct adopted in Venice.

The association has 100 active members. The members are employed in public and private companies, public sector organisations, non-profit organisations and PR-agencies. There are 100 professionals who are members of the organization. (EPRA 2019)

\section{EMPIRICAL STUDY}

The objective of the study is to describe the problems arising from the reorganisation of the traditional areas of activity by professionals operating in the field of public relations - in the context of content marketing, and from the viewpoint of representatives of PR agencies.

The following questions were posed:

1) What is content marketing from the viewpoint of Estonian PR specialists?

2) How have the fields of interest and activities of different parties in the communications market changed in the Estonian content marketing context?

3) Which problems and/or benefits are anticipated from these changes?

A qualitative approach was used in the study. According to Creswell (2014:44), qualitative research begins with assumptions, and the use of interpretative/theoretical frameworks that inform the study of research problems, which address the meanings, individuals or groups ascribe to a certain social or human problem. In qualitative studies, researchers try to develop a complex picture of the problem. This involves reporting multiple perspectives, identifying the factors in a situation and sketching out the larger picture by identifying the complex interactions, or factors in any situation.

The concept of purposeful sampling was used. In this case the researcher selects individuals for the study because they can purposefully form an understanding of the research problem, and central phenomena in the study (ibid., 156). From the standpoint of the study, respondents with a long service history in the field of public relations provide more qualitative information, as their opinions, concepts and experiences cover former, as well as current practices in the Estonian PR industry.

Therefore, the criteria for inclusion of respondents in the study sample were chosen as follows: 1) continuous service in the field of public relations over a 10 year period, i.e. the personal experience of the respondent covers approximately half of the history of Estonian PR as a sector of the economy; 2) current employment in a PR agency; 3 ) having at least the position of a senior consultant.

Participants of the sample were specified based on their inclusion in the list of members published on the website of the Estonian Public Relations Association. 19 persons meeting the criteria of the sample were identified out of 100 persons included in the list. This was accomplished with the assistance of an expert on the history and market of Estonian PR, with four of whom an in-depth interview was conducted at the beginning of May 2018. The age of the respondents was between 40-55 years old, and they represented agencies with 5-10 employees. Three of the four, represented agencies which have been in operation for over 10 years, and one for 3 years; one of the agencies counts itself among the 10, economically, most successful PR agencies in Estonia as of 2017.

The interviewer proceeded using the plan of a semi-structured interview, 
whereby the following topics were covered:

1) the nature of content marketing, current practices, and the changes in practices over time during the personal career of the respondent; 2) both the former and current practices of other parties in the market and the field of content marketing; 3) the problems and risks that have developed based on the current practices. Additional and clarifying questions varied by respondent, as they came about, or were developed during the course of interview, based on the answers provided. The duration of interviews also varied, from between 1 to 1.5 hours.

Recordings of the interviews were transcribed based on speech and the transcriptions were kept anonymous. The combined approach of thematic and open coding was used for organizing of the textual material. The investigators also performed content and discourse analysis of the text, first working independently, then comparing the findings and placing them into the context of other open sources.

Limitation of the survey might be seen in the low number of respondents (4), which is more common for a pilot study. However, taking into account the rather small market size of Estonia and the fact that the survey target group (senior specialists working in a PR agency for over 10 years) consists of only 19 people, there is a higher than average probability that the main arguments, points of view, and dominant discourses have been adequately covered in the study.

\section{RESULTS}

Nature and meaning of content marketing In rare cases content marketing was mentioned as a potential communication strategy, but mainly as a tactical solution. Among various forms and channels of content creation, audiovisual options were brought up in a few instances (i.e. bloggers, influencers, TV and radio broadcasts, and films), but generally the discussions concentrated mainly on written texts. To describe the nature of content marketing, the respondents used such terms as "paid advertising text", "advertising text", "advertising article", "commercial texts", "concealed advertising", "article marked as "content marketing ", " article purchased by a customer in media", "updated form of commercial text", "press-like product". It can be seen that for PR specialists, content marketing is mainly related to print or online media.

Content marketing is an advertising article introducing a service or product in a way suitable for the company. /interview 3/

Thus it can be said that currently, the term is used in Estonia simultaneously with both a very narrow, and in a more broad contextual sense (i.e. "article marked as "Content marketing” vs "marketing position of message") and it should be noted that the respondents themselves also admitted the terminological confusion:

There is no single definition or concept of content marketing, everyone is using it based on their current needs or opinions. /interview 4/

\section{Perceived changes}

According to the opinions of PR specialists, content marketing in the form of a paid commercial article is not a new phenomenon in the Estonian market. The name has merely changed (what was formerly 'commercial text' has now become 'content marketing'), and from the point of view of the audience, legibility of that content is actually better today: an advertising space filled with text has become an article. First and foremost, the behaviour of media has changed.

However, as the respondents indicate the editors have become more cautious against such proposed content, and therefore tend to send the text to the advertising sales department, even in the case of the smallest hint or signs of branding (e.g. name of brand, product or importer etc.). Another negative change for PR is active 
sales (including the creation and placement) of content marketing texts by media.

\begin{abstract}
„You can receive a call from the advertising department, that we will not publish it as news, or will publish as small text, but it has potential for content marketing and we can help you to write a relevant content marketing article for a specific price" /interview 3/
\end{abstract}

It was said that stronger interactions between the media and public relations sectors forces the operating practices of the public relations industry to adapt to these new conditions: a) by accepting offers of media (adaptation) or b) by developing their own professional skills and methods for using the provided content free of charge. The respondents condemned the hypocritical behaviour of the media, where content marketing activities and the shifting of borders are not always admitted to:

"They deny that they sell news. /.../ every media organization, which we have contacted, has set a barrier - they say that we are an interested party and do not want anybody to seize the market. This is a topic never discussed. Even the ethics adviser (of a media channel) never talks about it, as this is a possibility to earn extra money and survive." /interview 3/

\section{Potential benefits and damages}

The benefits and damages proceeding from the broader use of content marketing (here: in this case, mainly paid texts) mentioned in the interviews are specified in Table 1.

Analysis of the content of the texts, comprising the interviews, revealed three different notions of content marketing: „attribution and distancing“, „deception and trust", and the discourse that „nobody wins“. All of these points illustrate the current contradictory meaning of content marketing as a phenomenon, from the point of view of Estonian PR specialists.
The notion of 'attribution and distancing' was based on and predominantly former attitudes. The kind of concepts and ideas which highlight the importance and professionalism of the work of a PR specialist. Content marketing as an activity, has been attributed to public relations based on the similarity of its formal methods and aims.

We should not fear such things as content marketing or the influencers of social media /.../ we actually have known about these methods for a long time already and have used them ourselves /.../ also, the nature of PR activities relies on the creation of texts /interview 1 .

Then we have the concept of distancing:
"The task of a good PR expert is to make all information flow as digestible and interesting as possible for media, and in order to avoid payment for it. Content marketing is like a path of least resistance /.../ the press release is not well accepted, so let's buy the article /.../ it may lower our general professionalism, if we allow ourselves to play too much with it." /interview $1 /$.

As distancing and attribution were mentioned simultaneously by one person, this refers to inconsistency between the former role model and the new practice.
"I say at once that I do not write advertising articles, yet I have done it once or twice... the initia- tive came from the journalist. /..../ my interest was that the publi- cation would write and publish it, but the publication was inter- ested to get money." /interview 2/

\section{The discourse "Nobody wins"}

The term discourse is used here as in the recent Macnamara study - both in its 
PR as an industry
Getting something published in the media becomes mainly for pay.

The media does not accept any more PR texts after the content has already been paid for. The professional level of PR specialist lessens, because the motivation for writing stories fit for news decreases. Decrease in the reliability of the media is no longer in the interest of public relations.
Getting the message published by the media is ensured. Journalists write stories as subcontractors: a high-quality and cost-effective result for a PR agency.

Clear relations with the media, no need for lobbying.

The customer chooses content marketing instead of an advertisement (or advertising text).
Journalism as an industry
General reliability of journalistic content decreases, when the audience notices concealed advertising in the form of paid texts.

Journalists or publications lose their value for readers.

Role conflicts of journalists.
Journalists can earn extra income.

Turnover in advertising sales of media organisations increase.

Marketers begin to believe that concealed advertising sells better.

Demand arises for „ad-free“, paid online/ digital media.
Advertising as an industry

Customer of communication service

Creative agencies lose their income base.

Starting or small companies can no longer get their message into media channels (market barrier).

Additional content creation partner, media - duplication risk of activities.

Increased probability of publishing unprofessional texts, which damage reputations.

Control over published content (e.g. bloggers, influencers) weakens.

Compared to PR text, paid content has lower credibility. The assessment of the results may be biased, if a media house creates content, sells space online, and assesses the results themselves.

\section{/Not mentioned/}

Higher probability to get message their message into the media.

Broader communication and marketing possibilities (beneficial mainly for customers with a large budget). Allegedly, content marketing „,sells“ better than advertising.

The possibility to get into the public eye with authentic content. Results are measurable in web similar to advertising.
Audience/the public
Media that is comprised of paid content, creates a biased view of reality. It becomes increasingly difficult to discern paid content from actual journalistic material; groups interested in the message become hazy and distorted. Creators of the content may not be completely honest.

The press is not responsible for the integrity of the published information professional filters diminish or disappear. The responsibility and risks of the individual during the interpretation and use of published information increases.

Surveillance fee of electronic channels/ publications shall be paid for discarding paid content.
Advertising texts have become more relevant and interesting.

TABLE 1. Benefits and damages caused by the increase in volume of content marketing texts to different parties from the point of view of public relations. 
general linguistic sense denoting a body of discussion and in the critical post-modern sense in which it is seen as a social construction of reality that both usefully informs us of "truths" as well as being potentially misleading, and misrepresentative (Macnamara 2016).

The notion of deception and trust appeared for all related parties (i.e. audience, customers, media, PR), as well as in the term „concealed advertising“ in the description of the nature of content marketing. Unmarked texts „deceive the reader“, a good PR specialist „does not deceive journalists“, the media channel „denies (falsely) content marketing activities". The result is mutual distrust and results in the situation, 'where nobody wins'.

New practices created/offered by the media was related to all parties, except the advertising industry. The latter was rarely mentioned in the interviews, which infers that this player is not considered important in the concept of content marketing. The interviews mainly concentrated on the potential risks, concluding that „no party will win“ within the relatively new practice. The cycle of cause and consequence providing the basis for this argument is illustrated in Figure 1.

Content marketing helps the customers to fulfil short-term marketing objectives, because advertising in the form of journalistic content is more convincing than regular advertising, but, upon the saturation of media with content marketing texts, the initial method will depreciate, along with the improvement of media literacy of the reader and/or the loss of interest in content marketing texts. On the upper end is the number of paid for or sponsored texts, on the lower end is the probability that a reader would find balanced facts, which represent the public interest, and are also fact-checked by a journalist. However, the very need to do so, in turn damages reliability. When the trust of the audience is lost or decreases, all three parties lose from the market situation. PR specialists lose their former job in the field of media relations to the press, press publications lose their readers, and marketing will need to find another new method for providing essential information to the consumers, in addition to advertising. If everyone loses, then who wins?

\section{DISCUSSION}

All of the sources show that the media, the press, and related fields are no longer operating based on the former rules and business models, while new models have not yet developed to the point of sustainable maturation, which leaves the field in a confused state of flux.

What is 'content marketing' from the point of view of an experienced representative of an Estonian PR agency? This question intended to both find out how they define the term as well as describe the phenomenon. The results show that there is no single opinion which can properly define the term or phenomenon. However, it is visible that content marketing is understood as a service provided and enabled by the media, which has the ability to cause harm to the direct business interests of PR specialists, as well as to question the reliability of the press itself.

Public relations can be described as a field similarly to that of journalism (Bourdieu 1995). Content marketing does however, provide potential opportunities to both fields. Thus content marketing is a game changer, as writing has always been a core skill set of PR specialists (Cutlip 2000; Hardin, Pompper 2004), and therefore a tool used by players in the field. Interfering with another field's agents will change the rules of the game by altering traditional operations, disrupting business models, and also their credibility. The financial constraints are changing the traditional share of the market. Media as the owner of traditional information distribution channels also for content marketing articles. Therefore, as the respondents pointed out they are more appealing to the organizations who want their story to be told, as they can easily provide distribution channels. 


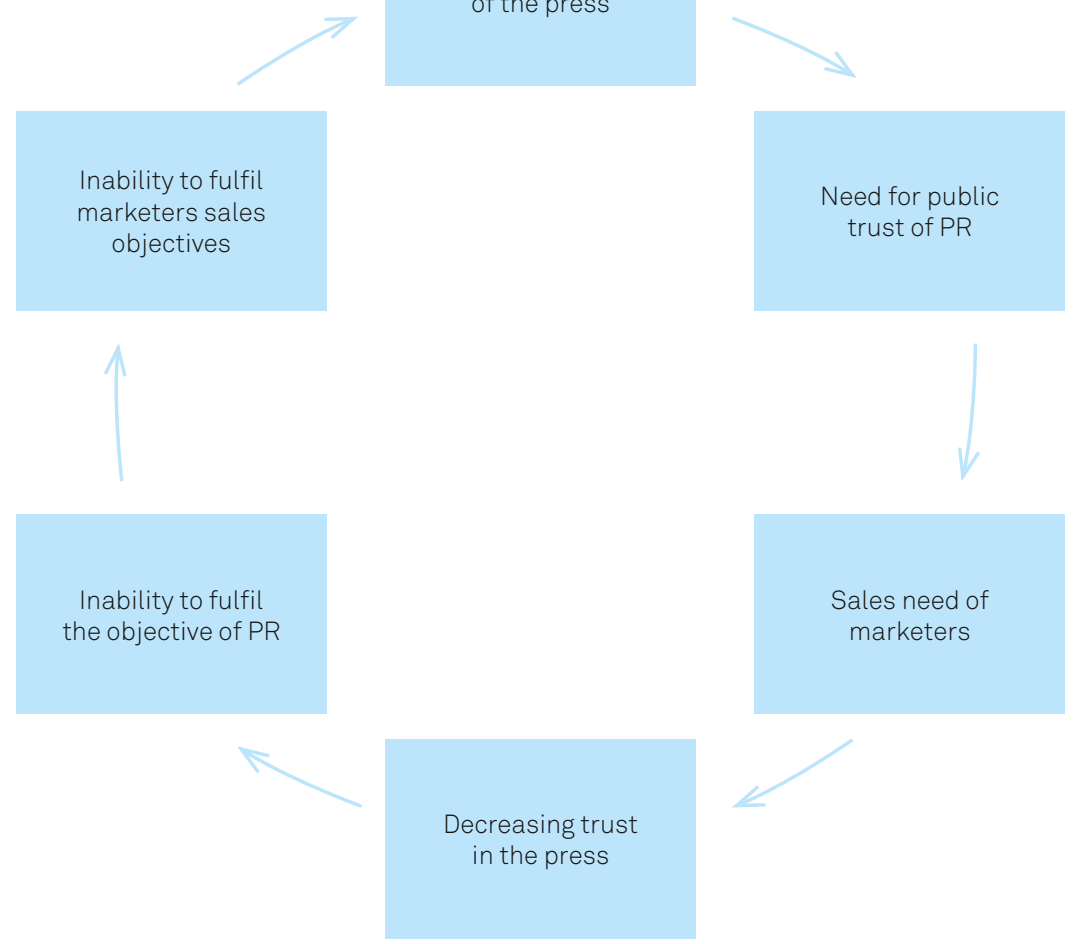

FIGURE 1. The discourse „nobody wins“: cause and consequence. 
The Estonian media market is small, and in certain corporate situations it is possible to manage for quite some time using tried and true traditions and habits - without the need to change the written or unwritten rules. However, such a model merely enables companies to cope with temporary deviations, not with new and growing trends. Just as a small society has the ability to make rapid changes and quickly adopt new phenomena, the increasing problems and challenges brought about by content marketing, may cause sudden, difficult to navigate reforms and crises. In the context of the topic, it can even mean that very sharp redistribution of fields of activity may take place, or that the specialists themselves may need to redefine their roles.

The Estonian Press Ethics Code originates from the period before online media (EALL 1998), The Media Services Act was adopted in 2010 (Riigi Teataja 2010), The Broadcasting Act in 2006 (Riigi Teataja 2007), and the 2016 version of The Advertising Act and its latest amendments do not include the topic of content marketing (Riigi Teataja 2008). Thus it can be concluded that the Estonian media regulation did not adapt to the changes in the media market, and any arising problems should be solved within the framework of and using the tools of existing regulations. The Empirical part of the study reveals that these tools are useless or inadequate in such a case, because one party of the market perceives sharpening problems clearly and strongly.

In regards to regulating the Estonian press, self-regulation is the primary system of control. Self-regulation documents, and guidelines are drafted by the EALL (Eesti Ajalehtede Liit - Estonian Newspaper Association), the non-profit, umbrella organization of Estonian media channels. The Estonian Press Council (PN), part of the same organization, has a major social role among various regulatory bodies, at the same time, content marketing has become an increasing source of income for the members of EALL thus, conflicts of interest are an issue which needs to be regularly considered and dealt with accordingly. Taking into account the nature of the problems revealed by this study, it may soon cause a major social conflict of values in the industry, and in society as a whole.

Trust and legitimacy are some of the central concepts in the PR field and it's important to keep in mind that today's practices should not affect the status of these concepts.

A risk for all sectors, which provide platforms for marketing communications as well as public relations initiatives, may be the decrease in trust by the end consumer. The objective of public relations, and more broadly the entire marketing communication field is to influence the efficiency of which depends also on the reliability of a media channel (Figure 1).

A decrease in the reliability of the press, is also a risk from the point of view of society as a whole. According to N. Luhmann (2000), trust is a solution for specific problems of risk. Trust is the phenomenon, which supports the reduction of the complexity of society (Luhmann 1979); trusting becomes the crucial strategy to deal with the uncertain, the unpredictable, and uncontrollable future (Sztompka 2003). A strong and independent press has always been a principle guarantee of democracy. The hybridization and commercialization of the press no longer fulfils the role entrusted to the press by society. In order to solve more complicated tasks or situations of society, as well as provide quality and impartial information, it is important to enable the people to access information from sources with the highest credibility.

\section{SUGGESTIONS}

The results of the current study suggest that the pressure between the fields of journalism, advertising and public relations in Estonia is intensifying. This poses new challenges to the professionals of each field to cope with financial pressures, ethical issues and the need to establish themselves in the new situation where traditional market shares have been shuffled. 
Current results suggest that the phenomenon of content marketing needs to be studied further. Current qualitative study of PR professionals need to be complemented with qualitative interviews of the news organizations' representatives. Furthermore, longitudinal study of content marketing articles will provide an understanding how the concept has changed over time.

Finally, in a social perspective, it is important to analyse all concerns and problems from the point of view of the media consumer, and the entire society. It is essential to understand, which consequences may arise from the decrease in transparency and reliability of the press, marginalization of the truth and core values of journalistic content as a quality, and the inclination of the advertising market towards various forms of native advertising.

\section{REFERENCES}

Avaliku Sõna Nõukogu 2019a. 'Mis on Avaliku Sõna Nõukogu?' http://www.asn.org.ee/mis_on_asn.html (28 September 2019).

Avaliku Sõna Nõukogu 2019b. 'Statistika'.

http://www.asn.org.ee/statistika.html (28 September 2019).

Benson, Rodney 2001. The Mediated Public Sphere: A Model for Cross-National Research. Working Paper Series. University of California Center for Culture, Organizations and Politics. Berkeley. http://www.irle. berkeley.edu/culture/papers/Benson01_08.pdf (24 April 2018).

Benway, Jan Panero; Lane, David 1998. "Banner Blindness: Web Searchers Often Miss "Obvious" Links'. - Internetworking Newsletter 11, 3, 1-11. Best Marketing 2015. 'Native advertising = sulanduv reklaam'. http://www.bestmarketing.ee/apps/pbcs.dll/ article?AID=/20150617/NEWS/150619970\&Show $=0$ (17 June 2015).

Bourdieu, Pierre 1995. 'The Political Field, the Social Science Field, and the Journalistic Field'. - Benson, Rodney; Neveu, Erik. (eds.) 2005, Bourdieu and the Journalistic Field. Cambridge. Polity Press 29-47. CIPR 2012. Share this : the social media handbook for PR professionals. Chartered Institute of Public Relations, Chichester, Wiley.

Creswell, John W. 2014. Qualitative inquiry \& research design. Choosing Among Five Approaches. $3^{\text {rd }} \mathrm{ed}$. Thousand Oaks. Sage Publications.

Cutlip, Scott; Center, Allen; Broom, Glen 2000. Effective Public Relations. Prentice Hall

EALL 1998. 'Eesti ajakirjanduseetika koodeks' http://eall.ee/eetikakoodeks.html (17 June 2015).

EALL 2004. 'Autoriõiguse hea tava lepe'.

https://www.eall.ee/uritused/2004/autorioiguse_hea tava.html (19 November 2018).

EALL 2005a. 'Ajalehe põhitunnused ja EALL liikmeks vastuvõtmise kriteeriumid'. https://www.eall.ee/ lepped/ajalehe_tunnused.html (19 November 2018). https://www.eall.ee/lepped/rekl_hea_tava.html (19 November 2018).

EALL 2005b. 'Artiklite refereerimise hea tava'. https://www.eall.ee/lepped/refereerimise_hea_tava. html (19 November 2018).

EALL 2008. 'Online kommentaaride hea tava lepe'. https://www.eall.ee/lepped/online.html (19 November 2018).

EALL 2015a. 'Telefonimüügi hea tava kokkulepe'. https://www.eall.ee/lepped/telefonimyyk.html (19 November 2018).

EALL 2015b. "Veebis vigade parandamise hea tava lepe'. https://www.eall.ee/lepped/vead.html (19 November 2018).

EALL 2016. 'Reklaami ja ajakirjandusliku sisu eristamise hea tava'. https://www.eall.ee/lepped/ rekl_hea_tava.html (19 November 2018).

EALL 2019a. 'Statistika 2007-2018'. http://eall.ee/ pressinoukogu/statistika.html (12 June 2018).

EALL 2019b. 'Pressinõukogu'. https://www.eall.ee/ pressinoukogu/index-eng.html (19 November 2018). EALL 2019c. 'Heat ava lepped'. https://www.eall.ee/ lepped/index.html (19 November 2018).

Eesti Otseturunduse Liit 2015. 'Telefonimüügi hea tava kokkulepe'. http://www.eotl.ee/hea-tava (19 November 2019).

EPRA 2019. 'Estonian Public Relations Association'. http://www.epra.ee/?page_id=189 (19 November 2019).

Flew, T., Waisbord, S. (2015), 'The ongoing significance of national media systems in the context of media globalization', Media, Culture and Society, Vol. 17, No. 4, pp. 620-636.

Fulton, J (2015), 'Are you a journalist? New media entrepreneurs and journalists in the digital space', Javnost, Vol. 22, No. 4, pp. 362-374. 
Hardin, M. and Pompper, D. (2004), 'Writing in the public relations curriculum: practitioner perceptions versus pedagogy', Public Relations Review, Vol. 30, No. 3, pp. 357-364.

Harro-Loit, Halliki; Saks, Kertu 2006. 'The diminishing border between advertising and journalism in Estonia'. Journalism Studies 7, 2, 312-322. https://doi.org/

10.1080/14616700500533635 (18 May 2018).

PriceWaterhouseCoopers 2009. 'Internet Advertising Revenue Report'. IAB = Interactive Advertising Bureau https://www.iab.com/wp-content/uploads/2015/05/ IAB-Ad-Revenue-Full-Year-2009.pdf (18 May 2018). PriceWaterhouseCoopers 2011. 'Internet Advertising Revenue Report'. IAB = Interactive Advertising Bureau. https://www.iab.com/wp-content/uploads/2015/05/ IAB_Internet_Advertising_Revenue_Report_FY_2011. pdf (18 May 2018).

PriceWaterhouseCoopers 2016. 'Internet Advertising Revenue Report'. IAB = Interactive Advertising Bureau. https://www.iab.com/wp-content/uploads/2016/04/ IAB_Internet_Advertising_Revenue_Report_FY_2016. pdf (18 May 2018).

Journalists.ee 2018. http://www.journalists.ee/ (12 June 2018).

Kantar Emor 2018a. 'Meediareklaamiturg tegi mullu jõulise kasvu'. https://www.emor.ee/pressiteated/ meediareklaamiturg-tegi-mullu-joulise-kasvu/ (19 February 2018).

Kantar Emor 2018b. 'Vähemalt kolmandik

veebireklaami rahast läheb välismaale'.

https://www.emor.ee/pressiteated/vahemalt-

kolmandik-veebireklaami-rahast-laheb-valismaale/

(27 February 2018).

Pihl, Katrin; Krusell, Siim 2019. Tulevikuvaade tööjõuja oskuste vajadusele - kultuur ja loometegevus: audiovisuaalvaldkond, sõna ja keel, turundus ja kommunikatsioon, disain ja kunst, trükitööstus. Uuringu lühiaruanne. Tallinn: SA Kutsekoda, tööjõuvajaduse seire- ja prognoosisüsteem OSKA

Kärtner, Isabel 2019. Sisuturunduse mõju suhtekorraldusele hetkel ja tulevikus. Bakalaurusetöö. Tallinna Ülikool, Balti filmi, meedia, kunstide ja kommunikatsiooni instituut. Tallinn.

Luhmann, Niklas 1979. 'Trust and Power'. Studies in Soviet Thought, 23, 3, 266-270.

Luhmann, Niklas 2000. 'Familiarity, Confidence, Trust: Problems and Alternatives'. - Gambetta, Diego (ed.), Trust: Making and Breaking Cooperative Relations. Electronic edition. University of Oxford, Department of Sociology, 94-107.

Luide, Lauri 2018. Sisuturundus Eesti ettevõtte ehk tellija vaatest. Bakalaurusetöö. Tallinna Ülikool, Balti filmi, meedia, kunstide ja kommunikatsiooni instituut. Tallinn.

Macnamara, Jim 2014. 'Journalism-PR relations revisited: The good news, the bad news, and insights into tomorrowss news'. - Public Relations Review, 40, 5, 739-750.

Macnamara, Jim 2016. 'The Continuing Convergence of Journalism and PR'. - Journalism \& Mass Communication Quarterly 93, 1, 118-141.

PageFair 2017. The state of the blocked web. 2017 Global Adblock Report. https://pagefair.com/ downloads/2017/01/PageFair-2017-Adblock-Report. pdf (28 August 2018).

Pulizzi, Joe 2015. 'Native advertising is not content marketing'. - Content Marketing Institute, 26. August. http://contentmarketinginstitute.com/2015/08/nativeadvertising-content-marketing (28 August 2018). Reporters Without Borders 2018. Barometer 2018. https://rsf.org/en/estonia (12 June 2018)

Riigi Teataja 2007. 'Estonian Public Broadcasting Act'. https://www.riigiteataja.ee/en/eli/509012014002/ consolide (19 November 2019).

Riigi Teataja 2008. 'Advertising Act'.

https://www.riigiteataja.ee/en/eli/504042018001/ consolide (19 November 2019).

Riigi Teataja 2010. 'Media Services Act'.

https://www.riigiteataja.ee/en/compare_original/

506112013019 (19 November 2019).

Rubin, Victoria; Chen, Yimin; Conroy, Niall 2015.

'Deception detection for news: three types of fakes'. Language and Information Technology Research Lab, Faculty of Information and Media Studies University of Western Ontario, London, Ontario, Canada.

https://onlinelibrary.wiley.com/doi/epdf/10.1002/ pra2.2015.145052010083 (19 November 2019). van Ruler, Betteke; Verčič, Dejan 2002. The Bled manifesto on public relations, Pristop Communications. Ljubljana.

Statistics Estonia 2018a. Computer and Internet users aged $16-74$ by group of individuals. Statistical database. http://andmebaas.stat.ee/Index.aspx?la ng=en\&SubSessionld =b5b5a1 c6-90ed-421f-a2d5c61 bacfcaa33\&themetreeid =6 (12 June 2018).

Statistics Estonia 2018b. Population at beginning of year. https://www.stat.ee/stat-population-atbeginning-of-year (9 May 2019).

Sztompka, Piotr 2003. 'Trust: A cultural resource'. Skapska, Grażyna (ed), The Moral Fabric in Contemporary Societies. Brill, Boston, 47-66. Taiminen, Kimmo; Luoma-aho, Vilma; Tolvanen, Kristiina 2015. 'The transparent communicative organization and new hybrid forms of content'. Public Relation Review 41, 5, 734-743.

TNS opinion \& social 2017. Media use in the European Union. Standard Eurobarometer 88. Report. European Commission. http://ec.europa.eu/commfrontoffice/ publicopinion/index.cfm/ResultDoc/download/ DocumentKy/82786 (18 June 2018).

TNS opinion \& social 2018. Public opinion in the EU regions. Standard Eurobarometer 90. Report. European Commission. https://ec.europa.eu/commfrontoffice/ publicopinion/index.cfm/Survey/getSurveyDetail/ yearFrom/1974/yearTo/2019/surveyKy/2219

(18 June 2018).

Vallade, Jilian 2009. 'Adblock Plus and the Legal Implications of Online Commercial-Skipping'. - Rutgers Law Review 7, 823-853.

Vihalemm, Peeter; Lauristin, Marju; Kalmus, Veronika; Vihalemm, Triin (toim) 2017. Eesti ühiskond kiirenevas ajas: uuringu "Mina.Maailm.Meedia" 2002-2014 tulemused. Tartu Ülikooli Kirjastus, Tartu.

Vohu, Silver 2016. Tarbija ostuotsuse juhtimine interneti sisuturunduslike vahenditega. Bakalaurusetöö. Tartu Ülikool majandusteaduskond.

Wojdynski, Bartosz; Evans, Nathaniel 2016. 'Going Native: The Effects of Disclosure Position and Language on Recognition and Evaluation of Online Native Advertising'. - Journal of Advertising 45, 2 , 157-168.

Wybenga, Ebele 2013. The Editorial Age. Adfo Groep, Amsterdam.

Zeng, Yuan 2018. 'Content marketing: marriage of journalism with marketing and advocacy rings alarm bells'. - Media Asia 45, 1-2, 44-48. https://doi.org/ 10.1080/01296612.2017.1533275 (3 March 2019).

Zerfass, A., Verčič, Dejan, Wiesenberg, M. (2016), 'The dawn of a new golden age for media relations?: How PR professionals interact with the mass media and use new collaboration practices', Public Relations Review, Vol. 9, No. 2, 499-508. 